\title{
EDITORIAL
}

\section{IVANI SANTANA}

GEORGE MASCARENHAS

\section{DRAMATURGIAS SEM \\ FRONTEIRAS: REORGANIZANDO TERRITÓRIOS E HORIZONTES}

\section{Pensar numa dramaturgia expandida é, talvez,} compreender que os artistas da cena são inventores que articulam com um entrelaçado de conhecimentos disponíveis no mundo, demonstrando que a contemporaneidade está para além de definições fixas. Esses artistas percebem a necessidade de olhar para além dos limites pretensos para suas linguagens, pois não têm interesse de aceitar barreiras empoeiradas por ditames de antigas convenções. Afinal, o que realmente delimitaria uma proposição artística se não a própria possibilidade criativa de uma pessoa? 
Expansão, nomadismo, reposicionamentos e cooperações são termos que podem ser percebidos nos movimentos dos artistas contemporâneos, inventores de suas proposições, mas também observados nas ações dos povos do mundo.

Estamos vivendo no século XXI por dobras e redobras, movimentos que, lastimavelmente, nos retrocedem e nos lançam para a frente ao mesmo tempo. Estamos no tempo já compreendido por uma velocidade - de tudo - acelerada, das novas noções de tempo e de espaço alterados, de embaralhamentos entre conhecimento, fato, informação e opinião - e fake news -, do reposicionamento de tudo em função de uma pandemia e consequente crise do sistema de saúde mundial - e que repentinamente alterou novamente o ritmo e velocidades das coisas, das pessoas e da vida -, da grave crise política polarizada por discursos bélicos, das reivindicações de um passado que retorna para cobrar justiça aos povos originários, das minorias e diversidade que exigem sim serem respeitadas, e assim por diante. Sem dúvida um contexto impossível de ser pensado localmente, por região, por fronteiras territoriais. A clara presença de que o planeta é um sistema completamente interligado, que todas as nações, sociedades e comunidades estão implicadas em algum nível - e com seu meio ambiente, são constatações que todos devem encarar na atualidade.

Portanto, pensar na arte com bordas, fronteiras e limites é não perceber que mesmo o mundo e sua divisão geográfica devem ser repensados. Os movimentos migratórios estão demonstrando que a identificação de uma unidade - um povo, por exemplo - deve ser por outra demarcação, pois é preciso repensar a definição de território.

As artes sempre estiveram para além de qualquer borda. Em toda sua história elas sempre mostraram que não tem muralhas definidoras que a delimitem. A arte é água que escorre por qualquer fenda, que arrebenta comportas quando se enfurece e vem com força, que evapora e torna a cair em outro canto, que flui sem pedir licença. A arte é substantivo feminino, sempre dá cria! 